\title{
BIO-CONTROL OF MULTIPLE DRUG-RESISTANT UROPATHOGENS USING MEDICINAL PLANT EXTRACTS
}

\author{
VIGI CHAUDHARY ${ }^{1}$, RAGHUVANSHI RK ${ }^{2}$, NAVEEN CHAUDHARY ${ }^{3}$, GAURAV SHARMA ${ }^{1 *}$
}

${ }^{1}$ Department of Microbiology, School of Applied Sciences, Suresh Gyan Vihar University, Mahal, Jagatpura, Jaipur, Rajasthan, India ${ }^{2}$ Department of Botany, University of Rajasthan, Jaipur, Rajasthan, India. ${ }^{3}$ Smile and Dental Care, Bhagwati Market, Achrol, Jaipur, Rajasthan, India. Email: jai_gaurav06@rediffmail.com

Received: 18 September 2018, Revised and Accepted: 01 November 2018

\section{ABSTRACT}

Objective: The present study was conducted to evaluate the potential of some medicinal plants used in Ayurveda in treating multiple drug-resistant human pathogens causing urinary tract infections (UTIs).

Methods: Dried parts of six medicinal plants used in Ayurveda for treating UTI were Soxhlet extracted, and the extract was concentrated in vacuo. Various concentrations of the extract were tested for antimicrobial activity against three clinical isolates of multiple drug-resistant bacteria causing UTI.

Results: Preliminary results showed the promising antibacterial effect of plant extracts. Escherichia coli, the most common pathogen associated with UTI, was susceptible to aqueous extracts of all the six medicinal plants.

Conclusion: This study concluded that the medicinal plants used in Ayurveda to treat UTIs are effective against multiple drug-resistant uropathogens. Further study in this regard may lead to the identification of novel antimicrobial agent for treating multiple drug-resistant urinary tract pathogens.

Keywords: Antibacterial activity, Ayurveda, Medicinal plant extract, Urinary tract infection.

(C) 2019 The Authors. Published by Innovare Academic Sciences Pvt Ltd. This is an open access article under the CC BY license (http://creativecommons. org/licenses/by/4. 0/) DOI: http://dx.doi.org/10.22159/ajpcr.2019.v12i2.29812

\section{INTRODUCTION}

Even though pharmaceutical industries have produced a number of new antibiotics, resistance to these drugs by microorganisms has increased. Each year, high mortality is caused in hospitals in developing countries due to antibiotic resistance [1]. Alarming multiple drug resistance has been reported among urinary tract infections (UTIs) [2]. Bacteria have the genetic ability to transmit and acquire resistance to therapeutic agents such as antibacterial drugs [3]. The most influential factor of antibiotic resistance is the inappropriate use of antibiotics [4]. The problem of microbial resistance is growing, and therefore, actions must be taken to reduce this problem. Certain such measures include controlling or restricting antibiotic usage; better understanding of the genetic mechanisms of resistance through advanced research, and developing new drugs, either synthetic or natural. To offer appropriate and efficient antimicrobial drugs to the patient should be the ultimate goal. Plants have been a valuable source of natural products for maintaining human health, especially in Ayurveda. More intensive studies for natural therapies have come up in the past decade [5-8]. The known antimicrobial properties of both plant extracts and phytochemicals can be of great significance in developing new therapeutic modalities in the fight against emerging multiple drug resistance among bacteria. The objective of this research was to evaluate the potential of plant extracts and phytochemicals on multidrug-resistant bacteria, which was isolated from patients having UTIs.

\section{METHODS}

\section{Bacteria}

Multiple drug-resistant microorganisms were isolated from urine samples of patients having UTI. Three most commonly found multiple drug-resistant bacteria, namely Escherichia coli, Staphylococcus aureus (coagulase-positive), and Pseudomonas aeruginosa were selected for the study. E. coli was resistant to ampicillin/sulbactam $(10 / 10 \mu \mathrm{g})$, cefazolin $(30 \mu \mathrm{g})$, ceftriaxone $(30 \mu \mathrm{g})$, cefepime $(30 \mu \mathrm{g})$, cefoxitin $(30 \mu \mathrm{g})$, cefoperazone $(75 \mu \mathrm{g})$, cefuroxime $(30 \mu \mathrm{g})$, ciprofloxacin $(5 \mu \mathrm{g})$, co-trimoxazole $(25 \mu \mathrm{g})$, doxycycline $(30 \mu \mathrm{g})$, and norfloxacin $(10 \mu \mathrm{g})$. Staphylococcus was resistant to ampicillin/sulbactam $(10 / 10 \mu \mathrm{g})$, cefazolin $(30 \mu \mathrm{g})$, cefuroxime $(30 \mu \mathrm{g})$, cefadroxil $(30 \mu \mathrm{g})$, co-trimoxazole $(25 \mu \mathrm{g})$, doxycycline $(30 \mu \mathrm{g})$, ofloxacin $(5 \mu \mathrm{g})$, and vancomycin $(30 \mu \mathrm{g})$. Pseudomonas was resistant to cefazolin $(30 \mu \mathrm{g})$, cefotaxime $(30 \mu \mathrm{g})$, cefepime $(30 \mu \mathrm{g})$, cefuroxime $(30 \mu \mathrm{g})$, ciprofloxacin $(5 \mu \mathrm{g})$, colistin $(10 \mu \mathrm{g})$, gentamycin $(10 \mu \mathrm{g})$, and imipenem $(10 \mu \mathrm{g})$. The antibiotic sensitivity discs were purchased from Pathoteq Biological Laboratories Ltd., Umbergaon, Gujarat.

The antibacterial activity of the plant extracts was also compared to the antibiotic sensitive bacterial strains, namely E. coli (MTCC 1652), S. aureus (MTCC 9542), and P. aeruginosa (MTCC 8165).

\section{Crude extract preparation of medicinal plants}

The medicinal plant parts were purchased from the local Ayurvedic market; identified and authenticated in herbarium of Department of Botany, University of Rajasthan, Jaipur. The plants and plant parts used for this study were Coriandrum sativum L. - seeds, Rotula aquatica Lour. - roots, Santalum album L.- stem, Elettaria cardamomum (L.) Maton- seeds, Piper longum L. - fruits, and Vitex negundo L. - roots. The plant samples were washed and air-dried under shade at room temperature for 7-10 days. After drying, the samples were reduced to small pieces, and the plant materials were grounded into a fine powder using mixer grinder. Pulverized samples were stored in airtight containers until further use. The powdered plant material was exhaustively extracted with methanol in a Soxhlet apparatus for $72 \mathrm{~h}$. The extract was filtered, and the clear supernatant was collected, covered, and labeled and used for the qualitative phytochemical screening $[9,10]$. The extract was then concentrated in vacuum. Various 
concentrations of the extract were tested for antimicrobial activity against three clinical isolates of multiple drug-resistant bacteria causing UTIs and three antibiotic sensitive strains obtained from IMTECH, Chandigarh. For aqueous extract preparation, the powdered plant parts were added to distilled water and boiled on slow heat for $2 \mathrm{~h}$. It was then filtered through eight layers of muslin cloth and centrifuged at $5000 \mathrm{rpm}$ for $10 \mathrm{~min}$. The supernatant was collected. This procedure was repeated twice. The supernatant collected at an interval of every $2 \mathrm{~h}$ was pooled together after $6 \mathrm{~h}$ and concentrated to reduce the final volume to one-fourth of the original volume. It was then autoclaved at $121^{\circ} \mathrm{C}$ and at $15 \mathrm{lbs}$ pressure and stored at $4^{\circ} \mathrm{C}$ until further use [11].

\section{Antibacterial activity of plant extract against uropathogens}

The methanolic extracts of medicinal plants were dried in vacuum using rotary vacuum evaporator. The dried plant extract was re-dissolved in dimethyl sulfoxide (DMSO) in the concentration $1 \mathrm{mg} / \mathrm{ml}$ and used for testing its potential antibacterial activity against uropathogens by agar well diffusion (agar cup) method on nutrient agar medium. The bacterial inoculum was spread uniformly on the medium using a sterile cotton swab. $5 \mathrm{~mm}$ diameter holes were cut in the agar gel, $20 \mathrm{~mm}$ apart from one another using sterile core borer. The media were incubated for $24 \mathrm{~h}$ at $36^{\circ} \mathrm{C} \pm 1^{\circ} \mathrm{C}$, under aerobic conditions after the addition of plant extracts into the wells. After incubation, confluent bacterial growth was observed. Inhibition of the bacterial growth was measured in $\mathrm{mm}[12,13]$.

The diameter of the zones of inhibition in the triplicate plates was measured and their mean designated as zone of inhibition. The activity indices were calculated as the division of zone of inhibition of the extract by that of the standard drug, that is, nitrofurantoin [14]. The activity index was calculated for the highest concentration of the plant extract tested as shown in Table 1 [15].

\section{Minimum inhibitory concentration (MIC)}

MIC was determined for extracts showing antimicrobial activity against test pathogens in well diffusion assay. For the determination of MIC values broth microdilution method was followed. Plant extracts were re-suspended in DMSO (which has no activity against test microorganisms) to make $15 \mathrm{mg} / \mathrm{ml}$ final concentration and then were added to broth media. $100 \mu \mathrm{l}$ inoculums of standard size were added to each test tube. Broth containing standard drug was used as positive control, and bacterial suspensions were used as negative control. The tubes were incubated at $37 \pm 2^{\circ} \mathrm{C}$ for $24 \mathrm{~h}$ for bacterial growth to occur. The MIC values were interpreted as the lowest concentration of the plant extract that prevented the visible growth of microorganisms as given in Table 2 [16].

\section{Phytochemical analysis of methanolic plant extracts \\ Test for alkaloids}

About $5 \mathrm{ml}$ of alcoholic extract was evaporated to dryness. The residues were taken in $5 \mathrm{ml}$ of $2 \%$ hydrochloric acid, saturated with sodium chloride and filtered. The filtrate was tested with Dragendorff's (potassium bismuth iodide) reagent (excess of KI + BiNO3 solutions). Presence of alkaloid produced brick red (reddish brown) colored precipitate.

\section{Test for flavonoids}

Ammonia test

Filter paper strips dipped in the alcoholic solution of the extract were ammoniated. The presence of flavonoids was indicated by the change in color of the filter paper to yellow.

\section{Test for coumarins}

About $1 \mathrm{ml}$ or $0.5 \mathrm{~g}$ of the plant extract was taken in a small test tube, and the mouth of the test tube was covered with filter paper moistened with $1 \mathrm{~N} \mathrm{NaOH}$. The test tube was placed in boiling water for a few minutes. Then, the filter paper was removed and examined in ultraviolet light for yellow fluorescence which indicated the presence of coumarins.

\section{Test for cardiac glycosides}

About $1 \mathrm{ml}$ of the plant extract was mixed with $2 \mathrm{ml}$ of glacial acetic acid, and few drops of $5 \%$ ferric chloride were added. $1 \mathrm{ml}$ of concentrated sulfuric acid was layered on it. Formation of a brown ring at interface indicated the presence of cardiac glycosides.

\section{Test for glycosides}

About $2 \mathrm{ml}$ of the plant extract was mixed with $3 \mathrm{ml}$ of chloroform and $1 \mathrm{ml}$ of $10 \%$ ammonium solution. Formation of pink color indicated the presence of glycosides.

\section{Test for phenolic compounds}

Ferric chloride test

About $3 \mathrm{ml}$ of alcoholic extract was evaporated to dryness and extracted with $5 \mathrm{ml}$ of distilled water. Few drops of neutral ferric chloride solution (5\%) were then added into the aqueous extract, dark green to blue color indicated the presence of phenolic compounds.

Table 1: Activity Index of medicinal plant extracts

\begin{tabular}{|c|c|c|c|c|c|c|c|}
\hline \multirow[t]{2}{*}{ S. No. } & \multirow{2}{*}{$\begin{array}{l}\text { Plant sample/name of bacteria } \\
\text { Solvent used }\end{array}$} & \multicolumn{2}{|c|}{ Pseudomonas aeruginosa } & \multicolumn{2}{|c|}{ Staphylococcus aureus } & \multicolumn{2}{|c|}{ Escherichia coli } \\
\hline & & МeOH & $\mathrm{H}_{2} \mathbf{O}$ & $\mathrm{MeOH}$ & $\mathbf{H}_{2} \mathbf{O}$ & МeOH & $\mathrm{H}_{2} \mathrm{O}$ \\
\hline 1 & Coriandrum sativum $\mathrm{L}$. & 0.35 & - & 0.55 & 0.59 & 0.83 & 0.568 \\
\hline 2 & Elettaria cardamomum (L.) Maton & 0.5 & 0.85 & 0.36 & 0.59 & 0.39 & 1.11 \\
\hline 3 & Piper longum L. & - & 0.69 & 0.63 & 0.82 & - & 1.22 \\
\hline 4 & Rotula aquatica Lour. & 0.38 & - & 0.55 & - & - & 0.83 \\
\hline 5 & Santalum album L. & 0.35 & - & 0.63 & - & 0.44 & 1.0 \\
\hline 6 & Vitex negundo L. & 0.54 & 0.42 & - & 0.68 & 0.67 & 1.05 \\
\hline
\end{tabular}

Table 2: Minimum inhibitory concentration of methanolic plant extracts $(\mathrm{mg} / \mathrm{ml})$ against uropathogens (clinical isolates)

\begin{tabular}{llll}
\hline S. No. & Plant sample & Pseudomonas aeruginosa & Staphylococcus aureus \\
\hline 1. & Coriandrum sativum L. & 1.875 & 3.75 \\
2. & Elettaria cardamomum (L.) Maton & 0.9375 & 0.4687 \\
3. & Piper longum L. & 1.875 & 3.75 \\
4. & Rotula aquatica Lour. & 1.875 & - \\
5. & Santalum album L. & 1.875 & 0.4687 \\
6. & Vitex negundo L. & 0.9375 & 0.9375 \\
\hline
\end{tabular}


Test for saponins

A few $\mathrm{ml}$ of the alcoholic extract was evaporated to dryness. To the residue, $6 \mathrm{ml}$ of distilled water was added, shaken well and observed for the presence of persistent foam indicating the presence of saponins.

\section{Test for sterols}

The alcoholic extract was tested for sterols by Salkowski reaction. In $2 \mathrm{ml}$ plant extract, $2 \mathrm{ml}$ chloroform, and $2 \mathrm{ml}$ of concentrated sulfuric acid were added and then shaken well. Chloroform layer appeared red and greenish yellow fluorescence developed in acid layer indicating the presence of sterols.

\section{Test for anthraquinone}

Borntrager's reaction for free anthraquinones

About $5 \mathrm{ml}$ of alcoholic extract was evaporated to dryness. To the residue $5 \mathrm{ml}$ chloroform was added. This was heated in a steam bath for $5 \mathrm{~min}$. The extract was filtered while hot and allowed to cool. To the filtrate, an equal volume of $10 \%$ ammonia solution was added. This was shaken, and the upper aqueous layer was observed for bright pink coloration indicating the presence of anthraquinones.

\section{Test for triterpenoids}

Salkowski test

About $2 \mathrm{ml}$ of plant extract was shaken with $2 \mathrm{ml}$ of chloroform, and 5 drops of concentrated sulfuric acid were added along the sides of the test tube. The appearance of reddish brown color at the interface indicates the presence of triterpenoids.

\section{Test for tannins}

To $3 \mathrm{ml}$ of plant extract, $3 \mathrm{ml}$ lead acetate solution was added. The occurrence of white precipitate indicated the presence of tannins.

\section{RESULTS}

The well size was $5 \mathrm{~mm}$ and zone of inhibition $>10 \mathrm{~mm}$ was considered to be significant. It was found that only $E$. coli were susceptible to methanolic extracts of $V$. negundo $L$. Methanolic extract of E. cardamomum (L.) Maton showed significant antibacterial activity against $P$. aeruginosa and some activity against $S$. aureus, but it was not effective against $E$. coli. Even though methanolic extract of $P$. longum L. was effective against Gram-negative bacteria P. aeruginosa and E. coli, it did not show any significant activity against Gram-positive bacteria S. aureus.

Methanolic extracts of $R$. aquatica Lour. were not effective against Pseudomonas but it was effective against both E. coli and S. aureus. S. album L. and C. sativum L. extracts showed significant antibacterial activity against all the test strains (Table 3 ).

When the same extracts were tested for its antibacterial activity against multiple drug-resistant clinical isolates causing UTIs, the results varied significantly. The multiple drug-resistant strains showed significantly lower susceptibility to plant extracts. It was found that E. coli were resistant to all the methanolic plant extracts except that of $C$. sativum $\mathrm{L}$. when $25 \mu \mathrm{l}$ of the plant extract were used. Pseudomonas was susceptible to three plant extracts only at the highest concentration tested. S. album L. and P. longum L. had antimicrobial activity only against Grampositive cocci ( $S$. aureus) whereas $V$. negundo L. was effective against Gram-negative bacteria E. coli and Pseudomonas. Elettaria cardomomum showed antimicrobial activity only against Pseudomonas (Table 4).

In traditional medicine as in Ayurveda, most of the time, the medicinal plant extracts used for treatments are produced by aqueous decoctions or infusions. To validate the use of these medicinal plants in the treatment of UTIs in Ayurveda, aqueous extracts were tested for antibacterial activity against clinical isolates causing UTIs. The results were overwhelming in the case of $E$. coli the most common uropathogens, as most of the aqueous extracts were potent than its corresponding methanolic extracts. P. aeruginosa was resistant to the aqueous extract of $C$. sativum L., R. aquatica Lour., and S. album L. which explains why multiple drug-resistant Pseudomonas is extremely difficult to control even by strong antibiotics. P. aeruginosa is also one of the notorious agents for nosocomial infections. S. aureus was resistant to R. aquatica Lour. and S. album L. E. coli were found to be more susceptible to aqueous extracts of medicinal plants in comparison to methanolic extracts (Table 5). P. aeruginosa was found to be resistant to most medicinal plant extracts while E. coli was found to be the most susceptible organism, especially to the aqueous extracts.

The activity index of aqueous extracts (Table 1) of E. cardamomum (L.) Maton, P. longum L., S. album L., and V. negundo L. was one and above

Table 3: Antimicrobial activity (ZI in $\mathrm{mm}$ ) of methanolic plant extracts against standard microbial strains

\begin{tabular}{|c|c|c|c|c|c|c|c|c|c|c|}
\hline \multirow[t]{2}{*}{ S. No } & \multirow[t]{2}{*}{ Plant sample/amount used } & \multicolumn{3}{|c|}{$\begin{array}{l}\text { Pseudomonas aeruginosa } \\
\text { (MTCC 8165) }\end{array}$} & \multicolumn{3}{|c|}{$\begin{array}{l}\text { Staphylococcus aureus } \\
\text { (MTCC 9542) }\end{array}$} & \multicolumn{3}{|c|}{$\begin{array}{l}\text { Escherichia coli } \\
\text { (MTCC 1652) }\end{array}$} \\
\hline & & $25 \mu \mathrm{l}$ & $50 \mu \mathrm{l}$ & $75 \mu \mathrm{l}$ & $25 \mu \mathrm{l}$ & $50 \mu \mathrm{l}$ & $75 \mu \mathrm{l}$ & $25 \mu \mathrm{l}$ & $50 \mu \mathrm{l}$ & $75 \mu \mathrm{l}$ \\
\hline 1. & Coriandrum sativum $\mathrm{L}$. & $8 \pm 0.22$ & $14 \pm 0.23$ & $18 \pm 0.53$ & $13 \pm 0.27$ & $15 \pm 0.2$ & $18 \pm 0.26$ & - & $8 \pm 0.22$ & $11 \pm 0.05$ \\
\hline 2. & Elettaria cardamomum (L.) Maton & $9 \pm 0.26$ & $17 \pm 0.38$ & $23 \pm 0.26$ & $6 \pm 0.05$ & $9 \pm 0.18$ & $11 \pm 0.12$ & - & - & $7 \pm 0.05$ \\
\hline 3. & Piper longum L. & $12 \pm 0.18$ & $15 \pm 0.07$ & $19 \pm 0.46$ & $6 \pm 0.05$ & $7 \pm 0.1$ & $9 \pm 0.18$ & $8 \pm 0.18$ & $9 \pm 0.05$ & $15 \pm 0.17$ \\
\hline 4. & Rotula aquatica Lour. & - & $6 \pm 0.18$ & $8 \pm 0.04 *$ & $7 \pm 0.02 *$ & $13 \pm 0.2^{*}$ & $17 \pm 0.17$ & $12 \pm 0.26$ & $19 \pm 0.5$ & $24 \pm 0.44$ \\
\hline 5. & Santalum album $\mathrm{L}$. & $6 \pm 0.1$ & $11 \pm 0.09$ & $15 \pm 0.28$ & $8 \pm 0.08$ & $12 \pm 0.3^{*}$ & $14 \pm 0.28$ & $9 \pm 0.1$ & $13 \pm 0.28$ & $18 \pm 0.1$ \\
\hline 6. & Vitex negundo L. & - & - & - & - & $7 \pm 0.07$ & $9 \pm 0.1$ & $14 \pm 0.46$ & $20 \pm 0.36$ & $22 \pm 0.27$ \\
\hline
\end{tabular}

Each value is expressed as mean \pm SD. $(n=3)$ and statistically significant at ${ }^{*} \mathrm{p}<0.05$. -: Means no zone of inhibition. ZI: Zone of inhibition, SD: Standard deviation

Table 4: Antimicrobial activity of methanolic plant extracts against clinically isolated multiple drug-resistant uropathogens (ZI in mm)

\begin{tabular}{|c|c|c|c|c|c|c|c|c|c|c|}
\hline \multirow[t]{2}{*}{ S. No. } & \multirow[t]{2}{*}{ Plant sample/amount used } & \multicolumn{3}{|c|}{ Pseudomonas aeruginosa } & \multicolumn{3}{|c|}{ Staphylococcus aureus } & \multicolumn{3}{|c|}{ Escherichia coli } \\
\hline & & $25 \mu \mathrm{l}$ & $50 \mu l$ & $75 \mu l$ & $25 \mu \mathrm{l}$ & $50 \mu \mathrm{l}$ & $75 \mu \mathrm{l}$ & $25 \mu \mathrm{l}$ & $50 \mu \mathrm{l}$ & $75 \mu \mathrm{l}$ \\
\hline 1. & Corian & $6 \pm 0.08$ & $7 \pm$ & $9 \pm$ & 3 & $12 \pm 0.22$ & $12 \pm 0.13$ & $12 \pm 0.36$ & $11 \pm 0.17$ & $15 \pm 0.28$ \\
\hline 2. & Elettaria cardamomum (L.) Maton & $7 \pm 0.15$ & $11 \pm 0.16$ & $13 \pm 0.2$ & - & - & $8 \pm 0.05$ & - & - & $7 \pm 0.1$ \\
\hline 3. & Piper longum L. & - & - & - & $8 \pm 0.15$ & $10 \pm 0.13$ & $14 \pm 0.18$ & - & - & - \\
\hline 4. & Rotula aquatica Lour. & - & $8 \pm 0.16$ & $10 \pm 0.15$ & - & $9 \pm 0.1$ & $12 \pm 0.18$ & - & - & - \\
\hline 5. & Santalum album L. & - & - & $9 \pm 0.05$ & $9 \pm 0.1$ & $12 \pm 0.15$ & $14 \pm 0.13$ & - & - & $8 \pm 0.13$ \\
\hline 6. & Vitex negundo L. & - & $8 \pm 0.06$ & $14 \pm 0.22$ & - & - & - & $7 \pm 0.1$ & $10 \pm 0.15$ & $12 \pm 0.17$ \\
\hline
\end{tabular}

Each value is expressed as mean $\pm \mathrm{SD}$. $(\mathrm{n}=3)$ and statistically significant at ${ }^{*} \mathrm{p}<0.05$. -: Means no zone of inhibition. SD: Standard deviation, ZI: Zone of inhibition 
Table 5: Antimicrobial activity (ZI in $\mathrm{mm}$ ) of aqueous plant extracts against clinically isolated multiple drug-resistant uropathogens

\begin{tabular}{|c|c|c|c|c|c|c|c|c|c|c|}
\hline \multirow{2}{*}{$\begin{array}{l}\text { S. } \\
\text { No. }\end{array}$} & \multirow[t]{2}{*}{ Plant sample/amount used } & \multicolumn{3}{|c|}{ Pseudomonas aeruginosa } & \multicolumn{3}{|c|}{ Staphylococcus aureus } & \multicolumn{3}{|c|}{ Escherichia coli } \\
\hline & & $25 \mu \mathrm{l}$ & $50 \mu \mathrm{l}$ & $75 \mu \mathrm{l}$ & $25 \mu \mathrm{l}$ & $50 \mu \mathrm{l}$ & $75 \mu \mathrm{l}$ & $25 \mu l$ & $50 \mu \mathrm{l}$ & $75 \mu \mathrm{l}$ \\
\hline 1. & Coriandrum sativum $\mathrm{L}$. & - & - & - & $8 \pm 0.05$ & $11 \pm 0.1$ & $13 \pm 0.23$ & - & - & $10 \pm 0.05$ \\
\hline 2. & Elettaria cardamomum (L.) Maton & $18 \pm 0.13$ & $19 \pm 0.1$ & $22 \pm 0.22$ & - & $11 \pm 0.16$ & $13 \pm 0.1$ & $10 \pm 0.13$ & $17 \pm 0.22$ & $20 \pm 0.27$ \\
\hline 3. & Piper longum L. & $12 \pm 0.07$ & $16 \pm 0.13$ & $18 \pm 0.1$ & $10 \pm 0.09$ & $12 \pm 0.18$ & $18 \pm 0.22$ & $13 \pm 0.22$ & $16 \pm 0.13$ & $22 \pm 0.27$ \\
\hline 4. & Rotula aquatica Lour. & - & - & - & - & - & - & $9 \pm 0.05$ & $12 \pm 0.1$ & $15 \pm 0.13$ \\
\hline 5. & Santalum album L. & - & - & - & - & - & - & $11 \pm 0.15$ & $14 \pm 0.2$ & $18 \pm 0.15$ \\
\hline 6. & Vitex negundo L. & - & $9 \pm 0.05$ & $11 \pm 0.09$ & - & $11 \pm 0.22$ & $15 \pm 0.1$ & $11 \pm 0.1$ & $13 \pm 0.17$ & $19 \pm 0.1$ \\
\hline
\end{tabular}

Each value is expressed as mean \pm SD. $(n=3)$ and statistically significant at * $\mathrm{p}<0.05$. -: Means no zone of inhibition. SD: Standard deviation, ZI: Zone of inhibition

against E. coli; which indicates the potential of these plants to control the growth of one of the most common uropathogens.

The zone of inhibition exhibited by nitrofurantoin against $P$. aeruginosa, S. aureus, and E. coli was $26 \mathrm{~mm}, 22 \mathrm{~mm}$, and $18 \mathrm{~mm}$, respectively.

The MIC required for no visible growth of the microorganisms was significantly higher (Table 2) compared to the agar well diffusion results. It may be noted that some methanolic plant extracts such as that of $R$. aquatica, P. longum L., E. cardamomum (L.) Maton, and S. album L. which did not show significant antibacterial activity against $E$. coli in the diffusion method (maximum concentration tested was $75 \mu \mathrm{g}$ ) also showed antibacterial activity in higher concentrations. This is an important observation which indicates that crude extracts may have to be used in higher concentrations for showing antimicrobial activity and to control uropathogens. This also signifies the need to isolate the active principle or the exact compound responsible for antibacterial activity from the crude extract to utilize it in lower concentrations and still show antibacterial activity.

Phytochemical analysis of plant extracts showed the presence of a variety of antimicrobial compounds such as alkaloids, flavonoids, triterpenes, polyphenols, and saponins (Table 6). The antimicrobial activity of the medicinal plant extracts needs to be investigated further to identify the compound/s responsible for bactericidal property and its mechanism of action.

\section{DISCUSSION}

Methanolic extract of $C$. sativum L. was effective against $E$. coli and $S$. aureus in higher concentrations. Antibacterial activity of the methanolic extract of $C$. sativum L. seeds is in agreement with a previous study conducted by Thangavel et al. [17]. Antibacterial activity of coriander methanolic extract against $E$. coli is in accord with an earlier report by Bonjar $[18,19]$. Coriander oil has been described in the past to be effective against Gram-negative (E. coli, Salmonella typhi, Klebsiella pneumonia, and Proteus mirabilis) and Gram-positive bacteria (Bacillus megaterium, S. aureus, and Bacillus sp.) [20-24]. According to Kubo et al., [25] dodecenal, isolated from fresh leaves of coriander showed bactericidal activity against Salmonella choleraesuis, a foodborne pathogen. Dodecenol proved to be twice as effective as gentamicin, the commonly used antibiotic administered to kill Salmonella. Campylobacter jejuni in raw meat could also be controlled using coriander oil in a dose-dependent manner [26]. The methanolic and aqueous extract of coriander seeds did not show any significant activity against $P$. aeruginosa. P. aeruginosa was resistant to coriander oil as described previously [24]. The aqueous extract was also not effective against $E$. coli. The inefficiency of aqueous extracts of Coriander against uropathogens has also been reported earlier $[27,28]$.

Both aqueous and methanolic extracts of E. cardamomum (L.) Maton showed significant antimicrobial activity against $P$. aeruginosa. E. cardamomum (L.) Maton aqueous extract was found to be the most effective against $P$. aeruginosa among all the medicinal plant extracts tested. Even though the methanolic extract did not show significant antibacterial effect on $S$. aureus and E. coli, the aqueous extract was effective against both the strains. The effectiveness of aqueous seed extract supports the use of E. cardamomum (L.) Maton decoctions in the treatment of UTIs in Ayurveda. The seed extract of cardamom in diethyl ether also showed antimicrobial activity against $P$. aeruginosa in an earlier study [29]. Antibacterial potential of E. cardomomum extracts against $S$. aureus has been demonstrated in earlier studies also [30].

P. aeruginosa and E. coli were resistant to methanolic extracts of $P$. longum L. However, the aqueous extract of $P$. longum L. showed significant antibacterial properties against $P$. aeruginosa, E. coli, and $S$. aureus. These results again support its use in Ayurveda to treat UTI. Both methanolic and aqueous extracts of $P$. longum L. showed significant antibacterial activity against $S$. aureus as reported by Sawhney et al. [31]. The antibacterial property of $P$. longum L. extracts has been established by many researchers before against Bacillus subtilis, S. aureus, Staphylococcus albus, S. typhi, P. aeruginosa, E. coli, and B. megaterium [32-34]. Piperine was more effective against $S$. aureus while piperlonguminine had activity against $B$. subtilis.

P. aeruginosa was resistant to both methanolic and aqueous extracts of $R$. aquatica Lour. This result is not in accord with the findings of a previous study by Prashanti et al. [35] where aqueous extract of $R$. aquatica Lour. roots was effective against $P$. aeruginosa. The aqueous extract of $R$. aquatica Lour. showed some activity against E. coli [36]. Another study reported that methanolic extract of $R$. aquatica Lour. showed antimicrobial activity against $E$. coli [37] which again was absent in the present study. Acetone extract of $R$. aquatica Lour. was found to be effective against uropathogens, namely E. coli, K. pneumoniae, and $P$. aeruginosa according to a recent study [38].

P. aeruginosa was resistant to both methanolic and aqueous extracts of S. album L. stem (heartwood). This finding was in accordance with the research reported by Parekh and Chanda [39]. Methanolic extract was effective against $S$. aureus whereas aqueous extract was effective against E. coli. The antimicrobial properties of S. album $L$. have been investigated by many researchers. Ethanolic extract was found to be effective against Bacillus cereus [40], and methanolic extract has been effective against B. subtilis [41,42], S. aureus, E. coli, K. pneumonia, P. aeruginosa [43] $P$. vulgaris, P. syryngea, and Xanthomonas malceverum [44]. The aqueous extract of $S$. album L. was found to be effective only against $S$. aureus [45].

Methanolic extract of $V$.negundo L. roots was not effective against $S$. aureus. The aqueous and methanolic extracts of $V$. negundo L. were moderately effective against the uropathogens in the highest concentration tested. The available literature supports the antimicrobial potential of $V$. negundo $L$. The essential oil of $V$. negundo $L$. showed antimicrobial activity against $S$. aureus and E. coli [46]. Water-ethanol (50:50) extract of $V$. negundo L. also found to be active against E. coli, P. aeruginosa, and S. aureus [47]. Menghani et al. [48] and Ahmad et al. [49] also reported the antimicrobial activity of ethanolic extract of $V$. negundo L. against E. coli, P. aeruginosa, and S. aureus. Methanolic leaf extract of $V$. negundo L. also showed antibacterial activity against B. cereus, E. coli, Klebsiella, P. aeruginosa, V. cholerae, S. pyogenes, B. subtilis, and S. aureus $[50,51]$. Chrysoplenol-(D), a phenolic isolated from $V$. negundo L., exhibited antibacterial activities against E. coli, B. subtilis, Micrococcus tetragenus, and Pseudomonas fluorescens [52].

The specific antimicrobial activity of various plant extracts against certain microorganisms is an interesting lead to explore the 


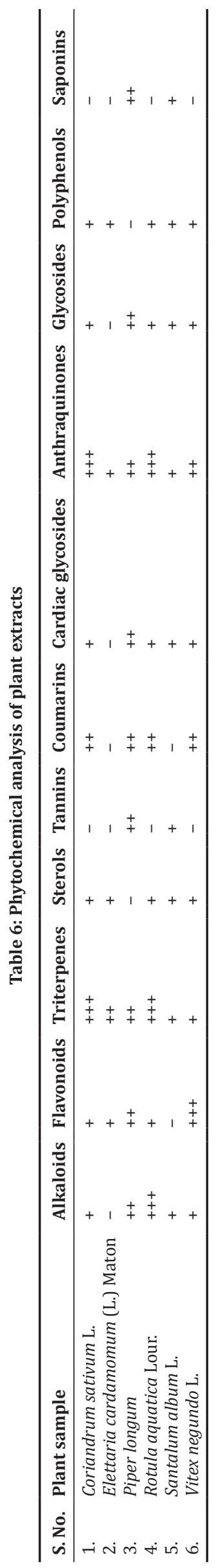

potential of these plants for developing alternative therapies for multiple drug resistance among bacteria. Dodecenol isolated from C. sativum L., piperine and piperlonguminine isolated from P. longum L., and chrysoplenol (D) isolated from V. negundo L. showed antibacterial properties. Although antimicrobial properties of E. cardamomum (L.) Maton, S. album L., and R. aquatica Lour. have been reported, we could not find any research data suggesting the compound responsible for the bioactivity in the plant extract. Furthermore, the mechanism of action of the plant extracts showing antimicrobial activity was not explored in any of the articles, to the best of our knowledge, except in the case of $C$. sativum L. oil. The primary mechanism of antimicrobial action of coriander oil was membrane damage leading to cell death as suggested by flow cytometry studies [53].

\section{CONCLUSION}

The data suggest that plant extracts have great potential as antimicrobial compounds against microorganisms. The study also throws some light into the traditional use of these medicinal plants in Ayurveda for the treatment of UTI seeing that the aqueous extracts of all six medicinal plants were effective against $E$. coli which are the most common causative agent of UTI. In the treatment of infectious diseases caused by antibiotic-resistant microbes, new molecules may be isolated from medicinal plants, as microbial resistance to the currently available drugs has become a global problem. The synergistic effect of various effective plant extracts is another area to be explored for potent drugs against multiple drug-resistant pathogens.

\section{ACKNOWLEDGMENTS}

The authors are grateful to Mr. Firoz for technical support and Dr. Zafar Rafique for his generous support in procuring urine samples and using the facilities at Meditech Clinical Laboratory, Jaipur.

\section{AUTHORS' CONTRIBUTIONS}

The study was conducted by the first author as part of her doctoral studies and guided throughout by the second author and corresponding author. The research paper was drafted by the first author and edited several times by the third author. Further revisions of the research article were done by the second and corresponding authors.

\section{CONFLICTS OF INTEREST}

The authors declare that they have no conflicts of interest regarding this research article.

\section{REFERENCES}

1. Gyles C. The growing problem of antimicrobial resistance. Can Vet J 2011;52:817-20

2. Chaudhary V, Sharma G, Chaudhary N, Raghuvanshi RK. High prevalence of multiple drug resistance among pediatric Escherichia coli infections. Int J Med Res Health Sci 2016;5:166-9.

3. Cohen ML. Epidemiology of drug resistance: Implications for a post - Antimicrobial era. Science 1992;257:1050-5.

4. World Health Organization. Antimicrobial Resistance: Global Report on Surveillance. Geneva: World Health Organization; 2014.

5. Scalbert A. Antimicrobial properties of tannins. Phytochemistry 1991;30:3875-83.

6. Eloff JN. Which extractant should be used for the screening and isolation of antimicrobial components from plants? J Ethnopharmacol 1998;60:1-8

7. Cowan MM. Plant products as antimicrobial agents. Clin Microbiol Rev 1999; 12:564-82.

8. Erdogrul ÖT. Antibacterial activities of some plant extracts used in folk medicine. Pharm Biol 2002;40:269-73.

9. Harborne JB. Phenolic compounds. In Phytochemical Methods. Dordrecht: Springer; 1984. p. 37-99.

10. Wagner H, Blandt S, Zgainski EM. Plant Drug Analysis. New York: Spring-Verlag; 1984. p. 320.

11. Satyanand TR, Amol PP, Ajeet S, Ashok B, Patel BD. Antibacterial activity of aqueous and ethanolic extracts of Scindapsus officinalis (Roxb.) Schott. Adv Biol Res 2011;5:77-80. 
12. Nascimento GG, Locatelli J, Freitas PC, Silva GL. Antibacterial activity of plant extracts and phytochemicals on antibiotic-resistant bacteria. Brazil J Microbiol 2000;31:247-56.

13. Smania A Jr., Monache FD, Smania ED, Cuneo RS. Antibacterial activity of steroidal compounds isolated from Ganoderma applanatum (Pers.) Pat. (Aphyllophoromycetideae) fruit body. Int J Med Mushr 1999;1:325-30.

14. Singh B, Sahu PM, Sharma MK. Anti-inflammatory and antimicrobial activities of triterpenoids from Strobilanthes callosus Nees. Phytomedicine 2002;9:355-9.

15. Dasgupta N, Ranjan S, Saha P, Jain R, Malhotra S, Saleh MA. Antibacterial activity of leaf extract of Mexican marigold (Tagetes erecta) against different Gram-positive and Gram-negative bacterial strains. J Pharm Res 2012;5:4201-3.

16. Basri DF, Fan SH. The potential of aqueous and acetone extracts of galls of Quercus infectoria as antibacterial agents. Indian J Pharm 2005;37:26.

17. Thangavel A, Balakrishnan S, Arumugam A, Duraisamy S, Muthusamy S. Phytochemical screening, gas chromatography-mass spectrometry (GC-MS) analysis of phytochemical constituents and anti-bacterial activity of Coraindrum sativum (L.) seeds. Int J Pharm Pharm Sci 2015;7:153-9.

18. Bonjar GS. Screening for antibacterial properties of some Iranian plants against two strains of Escherichia coli. Asian J Plant Sci 2004;3:310-4.

19. Bonjar S. Evaluation of antibacterial properties of some medicinal plants used in Iran. J Ethnopharmacol 2004;94:301-5.

20. Elgayyar M, Draughon FA, Golden DA, Mount JR. Antimicrobial activity of essential oils from plants against selected pathogenic and saprophytic microorganisms. J Food Prot 2001;64:1019-24.

21. Tolkunova NN. Effect of essential oils on microbiologic indices of meat products. In: Agropromizdat. Moskva: Pishchevaia Promyshlennost; 2002. p. 56-9.

22. Delaquis PJ, Stanich K, Girard B, Mazza G. Antimicrobial activity of individual and mixed fractions of dill, cilantro, coriander and eucalyptus essential oils. Int J Food Microbiol 2002;74:101-9.

23. Lo Cantore P, Iacobellis NS, De Marco A, Capasso F, Senatore F. Antibacterial activity of Coriandrum sativum L. And Foeniculum vulgare miller var. Vulgare (Miller) essential oils. J Agric Food Chem 2004;52:7862-6.

24. Matasyoh JC, Maiyo ZC, Ngure RM, Chepkorir R. Chemical composition and antimicrobial activity of the essential oil of Coriandrum sativum. Food Chem 2009;113:526-9.

25. Kubo I, Fujita K, Kubo A, Nihei K, Ogura T. Antibacterial activity of coriander volatile compounds against Salmonella choleraesuis. J Agric Food Chem 2004;52:3329-32.

26. Rattanachaikunsopon P, Phumkhachorn P. Potential of coriander (Coriandrum sativum) oil as a natural antimicrobial compound in controlling Campylobacter jejuni in raw meat. Biosci Biotechnol Biochem 2010;74:31-5.

27. Saeed S, Tariq P. Antimicrobial activities of Emblica officinalis and Coriandrum sativum against gram positive bacteria and Candida albicans. Pak J Bot 2007;39:913-7.

28. Saeed S, Tariq P. Antibacterial activities of Emblica officinalis and Coriandrum sativum against gram negative urinary pathogens. Pak J Pharm Sci 2007;20:32-5.

29. Ağaoğlu S, Dostbil N, Alemdar S. Antimicrobial effect of seed extract of cardamom (Elettarla cardamomum Maton). YÜ Vet Fak Derg 2006;16:99-101.

30. Aneja KR, Sharma C. Atimicrobial potetial of fruit extracts of Elettaria cardamomum Mato (chhoti elaichi) against the pathoges causing ear infection. Pharmacologyonline 2010;3:750-6.

31. Sawhney SS, Painuli RM, Chauhan NE. Evaluation of bactericidal and anticancer properties of fruits of Piper longum. Int J Pharm Pharm Sci 2011:3:282-7.

32. Reddy PS, Jamil K, Madhusudhan P, Anjani G, Das B. Antibacterial activity of isolates from Piper longum and Taxus baccata. Pharm Biol
2001;39:236-8.

33. Khan M, Siddiqui M. Antimicrobial activity of Piper fruits. Nat Prod Radiance 2007;6:111-3.

34. Ali MA, Alam NM, Yeasmin MS, Khan AM, Sayeed MA, Rao VB. Antimicrobial screening of different extracts of Piper longum Linn. Res J Agri Biol Sci 2007;3:852-7.

35. Prashanti P, Anita S, Shashidhara S. Studies on the antibacterial activity of the aqueous extract of the roots of Rotula aquatica Lour. Int J Fundam Appl Sci 2012;1:87-90.

36. Bency BT, Remya K, Smitha R, Shebina PR, Azeem AK. Rotula aquatica. Lour - A review on medicinal uses phytochemistry and pharmacological actions. Indian J Pharm Biol Res 2017;5:4-9.

37. Aswathanarayan JB, Vittal RR. In vitro evaluation of antioxidant and antibacterial activities of Rotula aquatica and Ancistrocladus heyneanus: Antioxidant and antimicrobial activity of medicinal plants. J Pharm Res 2013;6:313-7.

38. Raj KB, Joseph AV. Antibacterial potential of phytochemicals against urinary tract infectious bacteria. Int J Innov Res Dev 2016;5:94-9.

39. Parekh J, Chanda S. In vitro antimicrobial activity of some Indian folklore medicinal plants. J Cell Tissue Res 2006;6:577-80.

40. Dandge PB, Karajagi AB, Bhagwat PK, Bhise KK. Phytochemical profiling and antimicrobial potential of Santalum album L, Morinda citrifolia L. And Mucuna pruriens L. Res J Life Sci Bioinform Pharm Chem Sci 2016;1:265-72.

41. Parekh J, Jadeja D, Chanda S. Efficacy of aqueous and methanol extracts of some medicinal plants for potential antibacterial activity. Turk J Biol 2006;29:203-10.

42. Sivananthan M. Antibacterial activity of 50 medicinal plants used in folk medicine. Int J Biosci 2013;3:104-21.

43. Murugan VK, Arumugam T, Tamilvannan V, Umaarani K, Dhamotharan R, Ravikumar S. Phytochemical analysis and in vitro antibacterial properties of selected medicinal plants. Eur J Pharm Med Res 2015;2:189-94.

44. Hire KK, Dhale DA. Antimicrobial effect and in silico admet prediction of Santalum album L. Int J Pharm Bio Sci 2012;3:727-34.

45. Shamsi TN, Parveen R, Afreen S, Azam M, Fatma T, Haque QM, et al. In-vitro antibacterial and antioxidant activities of sandalwood (Santalum album). Austin J Biotechnol Bioeng 2014;1:3.

46. Nyiligira E, Viljoen AM, Bașer KH, Ozek T, Van Vuuren SF, Houghton PJ. Essential oil composition and in vitro antimicrobial and anti-inflammatory activity of South African Vitex Species. S Afr J Bot 2004;70:611-7.

47. Aswar PB, Khadabadi SS, Kuchekar BS, Rajurkar RM, Saboo SS, Javarkar RD. In-vitro evaluation of anti-bacterial and anti-fungal activity of Vitex nigundo (Verbenaceae). Ethnobotanical Leaflets 2009;2009:13.

48. Menghani E, Pareek A, Negi RS, Ojha CK. Search for antimicrobial potentials from certain Indian medicinal plants. Res J Med Plants 2011;5:295-301.

49. Ahmad N, Khan MI, Ahmed S, Javed SB, Faisal M, Anis M, et al. Change in total phenolic content and antibacterial activity in regenerants of Vitex negundo L. Acta Physiol Plant 2013;35:791-800.

50. Thombre R, Jagtap R, Patil N. Evaluation of phytoconstituents, antibacterial, antioxidant and cytotoxic activity of Vitex negundo L. and Tabernaemontana divaricata L. Int J Pharm Bio Sci 2013;4:389-96.

51. Prashith KT, Manasa M, Poornima G, Abhipsa V, Rekha C, Upashe SP, et al. Antibacterial, cytotoxic and antioxidant potential of Vitex negundo Var. Negundo and Vitex negundo Var. Purpurascens - A comparative study. Sci Technol Arts Res J 2013;2:59-68.

52. Ling TJ, Ling WW, Chen YJ, Wan XC, Xia T, Du XF, et al. Antiseptic activity and phenolic constituents of the aerial parts of Vitex negundo var. Cannabifolia. Molecules 2010;15:8469-77.

53. Silva F, Ferreira S, Queiroz JA, Domingues FC. Coriander (Coriandrum sativum L.) essential oil: Its antibacterial activity and mode of action evaluated by flow cytometry. J Med Microbiol 2011;60:1479-86. 